\title{
Occurrence of non-O157 Shiga toxin-producing Escherichia coli in dogs with diarrhea
}

\author{
Ocorrência de Escherichia coli não-0157 Shigatoxigênica em cachorros com diarréia
}

\author{
Cleber Jacob Silva de Paula ${ }^{\mathrm{I}}$ José Moacir Marin ${ }^{\mathrm{II}}$
}

\section{ABSTRACT}

Shiga toxigenic Escherichia coli (STEC) and Attaching and effacing $\mathbf{E}$. coli (AEEC) have been associated with diarrhea illness in dogs. From January to December 2006, 92 E. coli isolates from 25 diarrheic dogs were analyzed, by screening for the presence of Shiga toxin-producing (stx 1 and stx 2) and intimin (eae) genes. Twelve isolates were detected by PCR to harbor the Shiga toxin genes (7 the stx 1 (7.6\%); 5 the stx 2 (5.4\%); and none both of them). Nine (9.8\%) of the $\boldsymbol{E}$. coli isolates studied were eae positive non Shiga toxinproducing. Thirteen $(62.0 \%)$ isolates, carrying stx or eae gene, also showed $\alpha$ hemolysin production. The strains with virulence genes were also examined for resistance to 12 antimicrobial agents. Resistances to cephalothin (85.7\%), streptomycin (81.0\%), amoxicillin $(71.4 \%)$ and gentamicin $(71.4 \%)$ were predominantly observed.

Key words: Escherichia coli, STEC, eae gene, antimicrobial resistance.

\section{RESUMO}

Escherichia coli Shiga toxigênica (STEC) e E. coli Attaching- effacing (AEEC) têm sido associadas à doença diarréica em cachorros. Entre janeiro e dezembro de 2006, 92 cepas de $\boldsymbol{E}$. coli isoladas de 25 cachorros diarréicos foram examinadas. As cepas foram analisadas para a deteç̧ão dos genes produtores de Shiga toxina (stx 1 e stx 2) e da intimina (eae). Por meio de PCR foi observado que sete cepas $(7,6 \%)$ portavam o gene stx 1 , cinco cepas $(5,4 \%)$ carregavam o gene stx 2 e nenhum cepa apresentou ambos os genes associados. Nove cepas de E. coli $(9,8 \%)$ apresentaram o gene eae isoladamente. Treze das cepas $(62,0 \%)$ que apresentaram os genes stx ou eae também apresentaram a produção de $\alpha$ hemolisina. As cepas que apresentaram genes de virulência foram também examinadas em relação à resistência a 12 agentes antimicrobianos. As resistências mais comuns foram para cefalotina $(85,7 \%)$, estreptomicina $(81,0 \%)$, amoxicilina $(71,4 \%)$ e gentamicina $(71,4 \%)$.

Palavras-chave: Escherichia coli, STEC, gene eae, resistência antimicrobiana.

\section{INTRODUCTION}

Escherichia coli is a predominant component of the intestinal microbiota of humans and other mammals. Some E. coli strains represent primary pathogens having an enhanced potential to cause diseases, especially diarrhea (NATARO \& KAPER, 1998). An emergent pathogen, Shiga toxin-producing E. coli (STEC) of the serogroup O 157, designated as enterohemorrhagic $\boldsymbol{E}$. coli (EHEC), has been considered to be responsible for many outbreaks of hemorrhagic colitis and hemolytic uremic syndrome (PATON \& PATON, 1998). Two types of Shiga toxins, Stx1 and Stx 2 , are known and constitute the main virulence factors in STEC strains (PATON \& PATON, 1998). Domestic ruminants have been implicated as being the major reservoirs of STEC strains that cause human infections (CHAPMAN et al., 2001). However, other domestic animals like cats and dogs have also been found to carry STEC strains (BEUTIN et al., 1993; HAMMERMULLER et al., 1995; STAATS et al., 2003; BENTANCOR et al., 2007). In these cases, transmission pathways were the direct contact between humans and

\footnotetext{
'Programa de Pós-graduação em Microbiologia Agropecuária, Faculdade de Ciências Agrárias e Veterinárias, Universidade Estadual de São Paulo (FCAV/UNESP), Campus Jaboticabal, SP, Brasil.

"Departamento de Morfologia, Estomatologia e Fisiologia, Faculdade de Odontologia, Universidade de São Paulo (FORP/USP). Av. do Café, s/n, 14040-904, Ribeirão Preto, SP, Brasil. E-mail: jmmarin@forp.usp.br. Autor para correspondência.
} 
animals as well as fecal contamination (BENTANCOR et al., 2007). The STEC strain most frequently associated with clinical disease is the serotype O157:H7; nevertheless there are over one hundred of different serotypes of STEC strains, some of which are associated with human diseases (LAW, 2000). Since non-O157 strains are more prevalent in animals and as contaminants of food, humans are probably more frequently exposed to these strains (BLANCO et al., 2004).

Pets can be natural reservoirs of several organisms potentially able to cause disease to humans; children in special are central players in this crosstransfer game in view of their frequent nonobservance of proper hygiene habits (RODRIGUES et al., 2004). The eventual role of dogs as reservoirs of STEC strains has not been totally elucidated.

Attaching and effacing $\boldsymbol{E}$. coli (AEEC) are characterized as leading to diarrhea due to their ability to cause $\mathrm{A} / \mathrm{E}$ lesions in the gut mucosa of human and animal hosts. $\mathrm{A} / \mathrm{E}$ lesions are initiated by the intimate attachement of bacteria to enterocytes, mediated by intimin, an adhesin encoded by the eae gene (NATARO \& KAPER, 1998). Detection of this gene has been taken as an indication of the presence of the A/E pathogenicity factor in a given bacterial strain (KNUTTON et al., 1991). Natural infections with AEEC in dogs have also been described (BEAUDRY et al., 1996; NAKAZATO et al., 2004).

It has been shown that antimicrobials present in animals destined for alimentary purposes may contribute to selective antimicrobial resistance, posing risks to humans due to the transmission of resistant zoonotic bacteria via the food chain (WEGENER et al., 1999). Such resistant bacteria could be acquired by humans via alternative pathways including person-toperson transmission, environmental and/or direct exposure to animals. Cats and dogs represent potential sources for the spreading of antimicrobial resistance in view of the extensive use of antimicrobial agents in these animals, and their close contact with human beings (GUARDABASSI et al., 2004).

The aim of the present study was to study the occurrence of STEC strains in diarrheic dogs, as well as of their antimicrobial susceptibilities to 12 antimicrobial agents, as means to assess their importance as sources of infection.

\section{MATERIAL AND METHODS}

\section{Sample collection}

In order to establish STEC occurrence as well as their antimicrobial susceptibility to 12 antimicrobial agents, 25 diarrheic dogs were randomly selected by order of presentation to a private clinic in the city of Ituverava, State of São Paulo, between January and December 2006. Animals of any age, sex or breed were chosen on the following clinical inclusion criteria: acute hemorrhagic or not diarrhea, inappetence, no previous antimicrobial drugs treatment, with no other gastrointestinal disease or evidence of surgical approach. Samples collected by rectal swabbing with a sterile cotton swab under veterinary supervision were placed in Stuart transport medium and taken to immediate laboratory processing.

\section{Culture}

Samples were transferred to MacConkey agar (Mac-Difco) and incubated for $24 \mathrm{~h}$ at $37^{\circ} \mathrm{C}$. At least five colonies were selected from each plate for analysis. Biochemical confirmation of the strains as $\boldsymbol{E}$. coli was performed according to KONEMAN et al. (1997).

Determination of stx genes

Bacterial strains (E. coli isolates)grown overnight in nutrient broth (Sigma Chemical Co, St Louis, USA) at $37^{\circ} \mathrm{C}$, were tested for the presence of stx genes (stx 1 and stx 2) using the polymerase chain reaction (PCR) protocol of ORDEN et al. (1998). DNA templates were prepared by pelleting $1 \mathrm{ml}$ of culture enriched by centrifugation at $12000 \mathrm{~g}$. The cell pellet was resuspended in $250 \mu \mathrm{l}$ of sterile distilled water and boiled for $10 \mathrm{~min}$ at $100^{\circ} \mathrm{C}$, re-centrifuged and supernatants were subjected to PCR in an Eppendorf Mastercycler (Eppendorf AG, Hamburg, Germany). The amplified DNA products were separated by electrophoresis on $1.5 \%$ agarose gel, stained with ethidium bromide and examined for detection under ultraviolet light. Reference $\boldsymbol{E}$. coli strains used as controls were EDL 933 (O157:H7, stx1, stx 2, eae) and DH5a (negative control), both from Dr. Tânia A. Tardeli Gomes (Department of Microbiology, Immunology and Parasitology, Escola Paulista de Medicina, São Paulo, Brasil).

\section{Characterization of isolates}

Isolates were confirmed as stx + and tested for the accessory virulence marker eae, using the PCR protocol of CHINA et al. (1996).

\section{O157 latex agglutination}

STEC isolates were typed for O serotype O157 using the O157 Latex Agglutination test kit (Oxoid, Basingstoke, Hampshire, UK). The EDL 933 strain was used as a positive control. Strains negative to agglutination were considered non-O157 strains.

Ciência Rural, v.38, n.6, set, 2008. 
Susceptibility Testing

Antimicrobial disk susceptibility tests were performed using the disk diffusion method, according to the standards of the Clinical Laboratory Standards Institute (CLSI- formerly National Committee for Clinical Laboratory Standards-NCCLS, 2002,2003). Drugimpregnated disks (CEFAR, São Paulo, BR) were placed on the surface of the Mueller Hinton agar using a disk dispenser. The following twelve antimicrobial agents were tested: ampicillin (AMP, $10 \mu \mathrm{g}$ ); amoxicillin

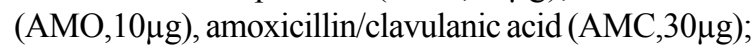
amikacin (AMK,30 $\mu \mathrm{g})$; cephalothin $(\mathrm{CFL}, 30 \mu \mathrm{g})$; ceftriaxone (CEF,30 $\mu \mathrm{g})$; gentamicin $(\mathrm{GEN}, 5 \mu \mathrm{g})$; streptomycin (STR, $10 \mu \mathrm{g})$; nalidixic acid (NAL, 30 $\mu \mathrm{g}$ ); cotrimoxazole (SUT, $25 \mu \mathrm{g}$ ); ciprofloxacin (CIP,5 $\mu \mathrm{g}$ ), tetracycline (TET, 30 $\mu \mathrm{g})$. E. coli ATCC 25922 and ATCC 35218 were included as recommended quality control strains, both from Adolfo Lutz culture collection (São Paulo, SP)

\section{RESULTS}

A total of $92 \boldsymbol{E}$. coli strains were isolated from 25 dogs with diarrhea. All E. coli isolates were investigated by PCR for the presence of Shiga-like toxin-producing genes (stx 1 and stx 2) and of the intimin (eae) gene. As it can be seen from table 1, 21 $(22.8 \%)$ of the strains carried the stx or the eae genes. PCR showed that $7(7.6 \%)$ of STEC strains carried only the st 1 gene, $5(5.4 \%)$ the st 2 gene, and none carried both stx 1 and stx 2 genes, $9(9.8 \%)$ strains carried only the eae gene. Twelve STEC isolates carrying stx 1 or stx 2 genes were isolated from 10 different dogs (10/25 - 40.0\%) (results not shown). All STEC strains isolated were tested by the $\mathrm{O} 157$ latex agglutination test kit, and not one $\mathrm{O} 157$ isolate was detected. There existed a positive correlation between $\alpha$-hemolysin production and the presence of stx or eae (13/21-62.0\%).

Among the 21 isolates carrying the stx or eae genes found, the highest resistance was showed against cephalothin $(85.7 \%)$, followed by those to

Table 1 - Virulence gene profile of Escherichia coli isolates from twenty-five diarrheic dogs (92 isolates) in Ituverava, State of São Paulo, Brazil, between January and December 2006.

\begin{tabular}{lcc}
\hline $\begin{array}{l}\text { Virulence factor } \\
\text { profile }\end{array}$ & $\begin{array}{c}\text { Number of isolates } \\
(\%)\end{array}$ & $\begin{array}{c}\alpha \text { hemolysin } \\
\text { Positive } \\
\text { isolate/total }\end{array}$ \\
\hline stx 1 & $7(7.6)$ & $2 / 7$ \\
stx 2 & $5(5.4)$ & $5 / 5$ \\
Eae & $9(9.8)$ & $6 / 9$ \\
Total & 21 & $13 / 21$ \\
\hline
\end{tabular}

streptomycin (81.0\%), amoxicillin (71.4\%) and gentamicin $(71.4 \%)$; low resistance to ceftriaxone $(0.0 \%)$ and to amoxicillin/clavulanic acid (14.4\%) was found (Table 2). No one isolate was susceptible to all antimicrobial agents tested.

\section{DISCUSSION}

A variety of $\boldsymbol{E}$. coli strains including the attaching and effacing $\boldsymbol{E}$. coli (AEEC) and the Shiga toxigenic $\boldsymbol{E}$. coli (STEC), has been associated with diarrheic illness in dogs (BEUTIN, 1999). Occasional isolation from both healthy and diarrheic dog feces have been reported (BENTANCOR, 2006)

The occurrence of stx genes among diarrheic animals (10/25 - 40.0\%) described in the present study, agree with the results reported by HAMMERMULER et al. (1995) showing $44.4 \%$ of such an outcome, as well as the presence of stx 1 and stx 2 genes but not of both together, in STEC isolates. Nevertheless, our results contrast with the report (HAMMERMULER et al., 1995) showing the predominance of the stx 2 gene among STEC isolates; in the present study, similar levels of stx $1(7.6 \%)$ and of stx $2(5.4 \%)$ genes were detected (Table 1).

Although the distribution of stx 1 and stx 2 genes found in diarrheic dogs agrees with that of other reports (STAATS et al., 2003; BENTANCOR et al., 2007), NAKAZATO et al. (2004) in Brazil did not find STEC strains carrying stx 1 or stx 2 genes among 146 diarrheic dogs and 36 healthy dogs analyzed. Furthermore, they did not observe a single O157:H7 strain among the animals examined.

The eae gene has been demonstrated in AEEC isolated from dogs, and attaching and effacing lesions have been found in dog intestinal tissue (BEAUDRY et al., 1996). Since the presence of the eae gene correlates with the attaching and effacing phenotype, the detection of this gene in $\boldsymbol{E}$. coli provides sufficient evidence to indicate potential virulence (NATARO \& KAPER, 1998). In the present study, four animals $(16.0 \%)$ presented AEEC strains with the eae gene, in agreement with the report of NAKAZATO et al. (2004), but it was less then reported by others (BEAUDRY et al., 1996; BENTANCOR et al., 2007).

KRAUSE et al. (2005) reported the isolation from dogs, of AEEC strains resembling typical enteropathogenic E. coli (EPEC) $(e a e+b f p \mathrm{~A}+)$, confirming other published data (GOFFAUX et al., 2000; NAKAZATO et al., 2004). Dogs live in close contact with humans and direct transmission of $\boldsymbol{E}$. coli strains is a probable occurrence. RODRIGUES et al. (2004) 
Table 2 - Antimicrobial susceptibility testing of $21 \boldsymbol{E}$. coli strains carrying stx or eae genes (virulence factors) isolated from diarrheic dogs in Ituverava, SP, BR.

\begin{tabular}{lccc}
\hline & & & \\
& & & \\
& & & \\
Antimicrobial drugs & Resistant & Intermediate & Sensitive \\
\hline Amikacin & 28.5 & 19.2 & 52.3 \\
Amoxicillin & 71.4 & 19.0 & 9.6 \\
Amoxicillin/ & 14.4 & 9.6 & 76.0 \\
clavulanic acid & & & \\
Ampicillin & 71.4 & 4.8 & 23.8 \\
Ceftriaxone & 0.0 & 33.3 & 66.7 \\
Cephalothin & 85.7 & 14.3 & 0.0 \\
Ciprofloxacin & 19.2 & 28.5 & 52.3 \\
Cotrimoxazole & 38.2 & 28.5 & 33.3 \\
Gentamicin & 71.4 & 9.6 & 19.0 \\
Nalidixic acid & 23.8 & 38.1 & 38.1 \\
Streptomycin & 81.0 & 14.2 & 4.8 \\
Tetracycline & 38.2 & 28.5 & 33.3 \\
\hline
\end{tabular}

demonstrated cross-infection between a dog and a child that lived in the same home in a city of the state of São Paulo, Brazil.

Hemolytic E. coli are a common occurrence both in healthy and in dogs with intestinal and extraintestinal infections (BEUTIN, 1999). $\alpha$-hemolytic activity was predominant (52.3\%), among the STEC isolates examined; however, the significance of $\alpha$ hemolysin production in strains causing enteric disease in dogs and its impact on potential virulence require further investigation.

Close contact between household pets and humans provides favorable conditions for the transmission of bacteria by direct contact (petting, licking, physical injuries, etc) or through the domestic environment (contamination of food, furnishings, etc). Children are at greater risk than adults, because of their closer physical contact with dogs as well as with household environment contaminated by pets. Bacteria resistant to antimicrobials selected for use in animal pets can reach a human host and exchange their resistance genes with bacteria residing in or on the host or vice versa (GUARDABASSI et al., 2004).

Members of most antimicrobials like tetracyclines, macrolides, lincosamides, aminoglycosides, penicillins and cephalosporins have for long periods been in use both in human and veterinary medicine; the same resistance genes have been identified in bacteria from humans and pet animals (PHILLIPS et al., 2004).

NORMAND et al. (2000) reported the results of analyses of $\boldsymbol{E}$. coli isolates obtained from clinical cases in companion animals (dogs and cats) in the United Kingdom between 1989 and 1997. The percentages of antimicrobial resistance described agree with those reported in the present study, except for gentamicin $(2.0 \%)$ and enrofloxacin (3.0\%). Although the authorization of fluoroquinolones for use in small animal veterinary practice is quite recent in Europe (mid 1990s), resistance to this antimicrobial class is appearing in pet animal bacteria (GUARDABASSI et al., 2004). In the present study the percentage of resistance to ciprofloxacin was high (19.2\%); the liberalization of this compound for veterinary use in Brazil is more recent than in Europe, and could indicate its misuse in veterinary practice in Brazil.

CARATTOLI et al. (2005) analyzed $298 \boldsymbol{E}$. coli isolates from specimens of 204 dogs submitted to routine diagnostic investigation in Italy between 2001 and 2003. The reported percentages of bacterial resistance were quite similar to that found in our study for tetracycline, nalidixic acid, cotrimoxazole and fluoroquinolones but very different regarding gentamicin $(8.1 \%)$ and amikacin $(0.7 \%)$.

To conclude, the present study showed the presence of STEC and AAEC strains in bacterial isolates from diarrheic dogs, as well as their high level of resistance to antimicrobial agents.

\section{REFERENCES}

BEAUDRY, M. et al. Genotypic and phenotypic characterization of Escherichia coli isolates from dogs manifesting attaching and effacing lesions. Journal of Clinical Microbiology, v.14, p.144-148, 1996.

BENTANCOR, A. Epidemiological role of pets in urban transmission cycle of STEC. Medicina, v.66, p.37-41, 2006.

BENTANCOR, A. et al. Shiga toxin-producing and attaching and effacing Escherichia coli in cats and dogs in a high hemolytic uremic syndrome incidence region in Argentina. FEMS Microbiology Letters, v.267, p.251-256, 2007.

BEUTIN, L. Escherichia coli as a pathogen in dogs and cats. Veterinary Research, v.30, p.285-298, 1999.

BEUTIN, L et al. Prevalence and some properties of verotoxin (Shiga-like-toxin)-producing Escherichia coli in seven different species of healthy domestic animals. Journal of Clinical Microbiology, v.31, p.2483-2488, 1993.

BLANCO, M. et al. Serotypes, virulence genes, and intimin types of Shiga toxin (verotoxin)-producing Escherichia coli isolates from cattle in Spain and identification of a new intimin variant gene (eae e). Journal of Clinical Microbiology, v.42, p.645-651, 2004.

CARATTOLI, A. et al. Extended-spectrum B-lactamase in Escherichia coli isolated from dogs and cats in Rome, Italy, frm 2001 to 2003. Antimicrobial Agents Chemotherapy, v.49, p.833-835, 2005.

Ciência Rural, v.38, n.6, set, 2008. 
CHAPMAN, P.A. et al. Escherichia coli O157 in cattle and sheep at slaughter, on beef and lamb carcasses, and in raw beef and lamb products in South Yorkshire, UK. International Journal of Food Microbiology, v.64, p.139-150, 2001.

CHINA, B. et al. Typing of bovine attaching and effacing Escherichia coli by multiplex in vitro amplification of virulence-associated genes. Applied and Environmental Microbiology, v.62, p.3462-3465, 1996.

GOFFAUX, F. et al. Genotypic characterization of enteropathogenic Escherichia coli (EPEC) isolated in Belgium from dogs and cats. Research Microbiology, v.151, p.865-871, 2000.

GUARDABASSI, L. et al. Pet animals as reservoirs of antimicrobial-resistant bacteria. Journal of Antimicrobial Chemotherapy, v.54, p.321-332, 2004

HAMMERMUELLER, J. et al. Detection of toxin genes in Escherichia coli isolated from normal dogs and dogs with diarrhea. Canadian Journal of Veterinary Research, v.59, p.265-270, 1995 .

KNUTTON, S. et al. Screening for enteropathogenic Escherichia coli in infants with diarrhea by the fluorescent-actin staining test. Infection and Immunity, v.59, p.365-371, 1991.

KONEMAN, E.W. et al. Color atlas and textbook of diagnostic microbiology. 5.ed. Philadelphia: Lippincott, 1997.

KRAUSE, G. et al. Investigation of domestic animals and pets as a reservoir for intimin-(eae) gene positive Escherichia coli types. Veterinary Microbiology, v.106, p.87-95, 2005.

LAW, D. Virulence factors of Escherichia coli O157 and other Shiga toxin-producing E. coli. Journal of Applied Microbiology, v.88, p.729-745, 2000.

NAKAZATO, G. et al. Attaching and effacing Escherichia coli isolated from dogs in Brazil: characteristics and serotypic relationship to human enteropathogenic E. coli (EPEC). Veterinary Microbiology, v.101, p.269-277, 2004.

NATARO, J.P.; KAPER, J.B. Diarrheagenic Escherichia coli. Clinical MIcrobiology Review, v. 11, p. 142-201, 1998.
NATIONAL COMMITTEE for CLINICAL LABORATORY STANDARDS. Performance Standards for antimicrobial disk and dilution susceptibility tests for bacteria isolated from animals; approved Standard-second edition M31A2. Wayne, P.A: National Committee for Clinical Laboratory Standards, 2002. V.22, n.6.

NATIONAL COMMITTEE for CLINICAL LABORATORY STANDARDS. Performance Standards for antimicrobial disk susceptibility tests; approved standards- $8^{\text {th }}$ edition M2-A8/M7-A6 and supplemented tables M100S14. Wayne, P.A: National Committee for Clinical Laboratory Standards, 2003 .

NORMAND, E.H. et al. Trends of antimicrobial resistance in bacterial isolates from a small animal referral hospital. Veterinary Record, v.146, p.151-155, 2000.

ORDEN, J.A. et al. Verotoxin-producing Escherichia coli (VTEC) and eae-positive non-VTEC in 1-30 days-old diarrhoeic dairy calves. Veterinary Microbiology, v.63, p.239-248, 1998.

PATON, J.C.; PATON, A.W. Pathogenesis and diagnosis of Shiga toxin-producing Escherichia coli infection. Clinical Microbiology Review, v.11, p.450-479, 1998.

PHILLIPS, I et al. Does the use of antibiotics in food animals pose a risk to human health? A critical review of published data. Journal of Antimicrobial Chemotherapy, v.53, p.28-52, 2004.

RODRIGUES, J. et al. Concurrent infection in a dog and colonization in a child with human enteropathogenic Escherichia coli clone. Journal of Clinical Microbiology, v.42, p.1338-1339, 2004.

STAATS, J.J. et al. Detection of Escherichia coli Shiga toxin and enterotoxin (est A and elt) genes in fecal samples from nondiarrheic and diarrheic greyhounds. Veterinary Microbiology, v.94, p.303-312, 2003.

WEGENER, H.C. et al. Transfer of antibiotic resistant bacteria from animals to man. Acta Veterinaria Scandinavica, v.92, p.51-57, 1999. 